\title{
EFFICACY OF Euphorbia hirta LATEX AS PLANT DERIVED MOLLUSCICIDES AGAINST FRESHWATER SNAILS
}

\author{
Ram P. YADAV(1) \& Ajay SINGH(2)
}

\begin{abstract}
SUMMARY
The toxic effect of binary and tertiary combinations of Euphorbia hirta Linn latex powder with other plant molluscicidal compounds, were evaluated against the freshwater snails Lymnaea (Radix) acuminata and Indoplanorbis exustus in pond. These combinations showed significant time and dose dependent effect against both the snails. These compounds at higher doses were also lethal to freshwater fish Channa punctatus (Bloch) (Channidae \{Ophicephalidae\}), which shares the habitat with these snails, but the $\mathrm{LC}_{90}(24 \mathrm{~h})$ doses of snails have no apparent killing properties in fish populations when treated in mixed population of snails and fish.
\end{abstract}

KEYWORDS: Euphorbia hirta; Molluscicide; Lymnaea acuminata; Indoplanorbis exustus; Fascioliasis control; India.

\section{INTRODUCTION}

The freshwater snails Lymnaea (Radix) acuminata (Lamarck 1822) and Indoplanorbis exustus (Deshayes 1834) are intermediate hosts of the liver flukes Fasciola hepatica (Linnaeus 1758) and Fasciola gigantica (Cobbold 1855) in northern part of India and cause endemic fascioliasis in cattle and livestock. Ninety four percent (94\%) of the buffaloes slaughtered in Eastern India were infected by F. hepatica ${ }^{19}$.

A sure way tackle the problem of fascioliasis is to destroy the carrier snails and remove an essential link in the life-cycle of the flukes by using molluscicide ${ }^{10,17,21,25}$. This can be achieved with the aid of synthetic products or, alternately, with molluscicides from plant sources. Molluscicides of plant origin have gained more acceptances, because they are ecologically sound and culturally more acceptable than synthetic ones $^{3,9,17,24,26,27,28}$.

Euphorbia hirta Linn. (family-Euphorbiaceae) is a common medicinal plant of India, which is used in a variety of diseases i.e., cough, asthma, colic dysentery, genitourinary diseases ${ }^{2,4,7,8,12}$.

In the present study to evaluate the molluscicidal activity of Euphorbia hirta latex powder is singly or binary (1:1) or tertiary combinations $(1: 1: 1)$ with other molluscicidal compounds i.e. rutin, ellagic acids, taraxerol and betulin against freshwater snails Lymnaea acuminata and Indoplanorbis exustus in pond.

\section{MATERIALS AND METHODS}

A. Preparation of extract: The latex of Euphorbia hirta was drained into glass tubes by cutting their stem apices. This latex was lyophilized at $-40{ }^{\circ} \mathrm{C}$ and the lyophilized powder was stored for further use. The dried powder was mixed with an appropriate volume of a distilled water to obtain the desired concentration. The latex powder so obtained was used for the toxicity testing of doses used in the earthen cemented pond.

The latex powder of E. hirta so obtained was used to evaluate for the toxicity in combination with different active compounds rutin, ellagic acids, taraxerol and betulin using doses against both the snails given in Table 1. Combinations of latex powder of E. hirta with rutin, ellagic acid, taraxerol and betulin prepared in organic solvent methanol of each plant products used in the singly, binary and tertiary mixtures dissolved in organic solvent methanol and used as a source for preparing the final concentration in the earthen cemented ponds.

Rutin $\left(\mathrm{C}_{27} \mathrm{H}_{30} \mathrm{O}_{16}\right)\left(\right.$ EC NO-205-814-1), Ellagic acid $\left(\mathrm{C}_{14} \mathrm{O}_{6} \mathrm{O}_{8}\right)$ (4,4,5,5,6,6-Hexahydroxydiphenic acid, 2,6,2,6-dilactone) (EC NO207-508-3) , Betulin $\left(\mathrm{C}_{30} \mathrm{H}_{50} \mathrm{O}_{2}\right)$ (Lup-20(2a)-ene-3 $\beta$-28-diol) (EC NO-207-475-6) supplied by Sigma Chemical Co. (P.O. Box 14508, St. Louis-Mo. 63178, USA, 314-771-5750). Taraxerol was extracted from the stem bark of Codiaeum variegatu ${ }^{23}$.

B. Experimental design: The live test animal of Lymnaea (Radix) acuminata (Lamarck 1822) $(2.6 \pm 0.3 \mathrm{~cm}$ in shell height) and Indoplanorbis exustus (Deshayes 1834) $(0.87 \pm 0.035 \mathrm{~cm}$ in shell height) were collected from the Ramgarh Lake of Gorakhpur district. The collected animals were maintained in glass aquaria containing $100 \mathrm{~L}$ dechlorinated tap water and acclimatized to laboratory conditions for $72 \mathrm{~h}$.

The toxicity experiment was designed singly, binary or in tertiary combinations by the methods of SINGH et al. ${ }^{18}$. The experiments were performed in two freshwater ponds of $29.28 \mathrm{~m}^{2}$ in area and $9.19 \mathrm{~m}^{3}$ in water

(1) Senior Research Associate, Department of Zoology, DDU, Gorakhpur University, Gorakhpur (U.P.)-273009, India. Phone: 09450436049. E-mail: rampratapy@ rediffmail.com 
YADAV, R.P. \& SINGH, A. - Efficacy of Euphorbia hirta latex as plant derived molluscicides against freshwater snails. Rev. Inst. Med. Trop. Sao Paulo, 53(2): 101-6, 2011.

Table 1

Concentrations used for toxicity test

\begin{tabular}{lcc}
\hline Treatments & \multicolumn{2}{c}{ Concentration used (mg/L) } \\
\cline { 2 - 3 } & Lymnaea acuminata & Indoplanorbis exustus \\
\hline Latex powder of E. hirta & $2.5,3.5,4.5,5.5$ & $1.0,2.0,3.0,4.0$ \\
Latex powder+Rutin & $0.3,0.6,1.0,1.5$ & $1.0,2.0,3.0,4.0$ \\
Latex powder+Ellagic acids & $1.5,2.0,2.5,3.0$ & $2.5,3.5,4.5,5.5$ \\
Latex powder+Taraxerol & $4.0,6.0,8.0,10.0$ & $7.5,9.5,11.5,13.5$ \\
Latex powder+Rutin+Betulin & $0.3,0.7,1.1,1.5$ & $3.0,4.0,5.0,6.0$ \\
Latex powder+Ellagic acids+Betulin & $0.7,1.0,1.3,1.6$ & $4.0,5.5,6.5,7.5$ \\
Latex powder+Taraxerol+Betulin & $1.5,2.0,3.0,3.5$ & $5.5,6.5,7.5,8.5$
\end{tabular}

volume. Each pond was stocked with 100 snails and these experimental ponds were exposed continuously for $96 \mathrm{~h}$ to four concentrations either singly, binary or in tertiary combinations of compounds (Table 1). Control group ponds were kept in similar conditions without any treatment. Water analysis for temperature, $\mathrm{pH}$, dissolved $\mathrm{O}_{2}$ free $\mathrm{CO}_{2}$ and total alkalinity was measured ${ }^{1}$. Water temperature ranged from $27.4-28.6^{\circ} \mathrm{C}$. The other parameters were within the following range: total alkalinity $43-62 \mathrm{ppm}$, $\mathrm{pH}$ 6.8-7.7, dissolved oxygen 7.8-10.3 mg/L.

Toxic effect of latex powder of E. hirta with other compounds was also studied in mixed populations of fish and snails. In these experiments a group of 50 snails Lymnaea acuminata and 50 fish Channa punctatus (Bloch) (Channidae [Ophicephalidae]) put together in $100 \mathrm{~L}$ de-chlorinated tap water. These mixed populations were exposed to previously determined $\mathrm{LC}_{90}(24 \mathrm{~h})$ of snails for $24 \mathrm{~h}$.

C. Determination of $\boldsymbol{L C}_{50}$ : Mortality of snails was recorded at $24 \mathrm{~h}$ intervals up to $96 \mathrm{~h}$. Lethal concentrations $\left(\mathrm{LC}_{50}\right)$ and their, upper and lower confidence limits (UCL, LCL) and slope values calculated by the probit log method using POLO computer programme ${ }^{15}$.

D. Statistical analysis: Student's t-test was applied to determine the significant $(\mathrm{p}<0.05)$ differences between treated and control animals. Analysis of variance was applied to determine the significant differences observed in the fecundity caused by the different combinations. Product moment correlation coefficient was applied in between exposure time ${ }^{22}$.

E. Ethical guidelines on treatment of animals: The experimental animal snails Lymnaea acuminata and Indoplanorbis exustus is an intermediate host of Fasciola hepatica which causes endemic fascioliasis, a common liver disease rot in the cattle of eastern Uttar Pradesh. The snails do not have any beneficial economic importance in the ecosystem. In fact the population management of snails will check this disease in the livestock. The department has enough facilities for the rearing and culture of these experimental animals. Work on snails was not the violation of animal ethics as they are not endangered species.

\section{RESULTS}

The toxicity of latex powder of Euphorbia hirta was also time and dose-dependent for the freshwater snails Lymnaea acuminata and
Indoplanorbis exustus in earthen cemented pond. There was a significant negative correlation among $\mathrm{LC}_{50}$ values and all the exposure periods for $24 \mathrm{~h}$ or $96 \mathrm{~h}$ (Table 2-3, Fig 1,2). Thus increase in exposure time, the $\mathrm{LC}_{50}$ of latex powder of $E$. hirta was decreased from $7.31 \mathrm{mg} / \mathrm{L}(24 \mathrm{~h}) ;>5.51$ $\mathrm{mg} / \mathrm{L}$ (48h); > $4.90 \mathrm{mg} / \mathrm{L}$ (72h); to $3.93 \mathrm{mg} / \mathrm{L}$ (96h) against snail Lymnaea acuminata and $6.08 \mathrm{mg} / \mathrm{L}(24 \mathrm{~h}) ;>5.33 \mathrm{mg} / \mathrm{L}(48 \mathrm{~h}) ;>3.17 \mathrm{mg} / \mathrm{L}(72 \mathrm{~h})$; $>$ to $2.30 \mathrm{mg} / \mathrm{L}$ (96h) against freshwater snail Indoplanorbis exustus.

In binary (1:1) combination latex+rutin against snail L. acuminata the value is decreased. $\mathrm{LC}_{50}$ is $1.02 \mathrm{mg} / \mathrm{L}(24 \mathrm{~h}) ;>0.76 \mathrm{mg} / \mathrm{L}(48 \mathrm{~h}) ;>0.61$ $\mathrm{mg} / \mathrm{L}(72 \mathrm{~h})$ and $0.51 \mathrm{mg} / \mathrm{L}(96 \mathrm{~h})$ respectively (Table 2$)$ and the freshwater snail I. exustus the latex powder+rutin is $4.45 \mathrm{mg} / \mathrm{L}(24 \mathrm{~h}) ;>3.30 \mathrm{mg} / \mathrm{L}$ $(48 \mathrm{~h}) ;>2.82 \mathrm{mg} / \mathrm{L}(72 \mathrm{~h})$ and $2.11 \mathrm{mg} / \mathrm{L}(96 \mathrm{~h})$ respectively and latex powder+ellagic acid $6.40 \mathrm{mg} / \mathrm{L} ;>5.44 \mathrm{mg} / \mathrm{L}(48 \mathrm{~h}) ;>4.55 \mathrm{mg} / \mathrm{L}(72 \mathrm{~h})$ and $3.70 \mathrm{mg} / \mathrm{L}(96 \mathrm{~h})$ respectively and latex powder+taraxerol is 14.41 $\mathrm{mg} / \mathrm{L}(24 \mathrm{~h}) ;>13.23 \mathrm{mg} / \mathrm{L}(48 \mathrm{~h}) ;>12.04 \mathrm{mg} / \mathrm{L}$ (72h) and $10.99 \mathrm{mg} / \mathrm{L}$ (96h) respectively against freshwater snail I. exustus (Fig 1).

In tertiary $(1: 1: 1)$ combinations of the latex powder+rutin+betulin against freshwater snail Lymnaea acuminata the $\mathrm{LC}_{50}$ value is 0.92 $\mathrm{mg} / \mathrm{L}(24 \mathrm{~h}) ;>0.67 \mathrm{mg} / \mathrm{L}$ (48h); > $0.57 \mathrm{mg} / \mathrm{L}(72 \mathrm{~h})$ and $0.47 \mathrm{mg} / \mathrm{L}(96 \mathrm{~h})$ respectively (Table 3), and the freshwater snail I. exustus the $\mathrm{LC}_{50}$ value decreases in the tertiary combination of latex powder+rutin+betulin is $7.80 \mathrm{mg} / \mathrm{L}(24 \mathrm{~h}) ;>6.30 \mathrm{mg} / \mathrm{L}(48 \mathrm{~h}) ;>5.53 \mathrm{mg} / \mathrm{L}(72 \mathrm{~h})$ and $4.22 \mathrm{mg} / \mathrm{L}$ (96h) respectively. Combination of latex powder+ellagic acid+betulin is significantly decreased, $7.90 \mathrm{mg} / \mathrm{L}(24 \mathrm{~h}) ;>6.47 \mathrm{mg} / \mathrm{L}(48 \mathrm{~h}) ;>5.66$ $\mathrm{mg} / \mathrm{L}(72 \mathrm{~h})$ and $5.11 \mathrm{mg} / \mathrm{L}$ (96h) respectively against snail I. exustus and in combination of latex powder+taraxerol+betulin is $9.28 \mathrm{mg} / \mathrm{L}(24 \mathrm{~h})$; > $7.99 \mathrm{mg} / \mathrm{L}(48 \mathrm{~h}) ;>7.13 \mathrm{mg} / \mathrm{L}$ (72h) and $6.56 \mathrm{mg} / \mathrm{L}$ (96h) respectively against the freshwater snail I. exustus (Fig 2).

In mixed of binary combinations (1:1), latex powder of $E$. hirta with rutin, ellagic acid and taraxerol was more toxic for freshwater snail $L$. acuminata and I. exustus as compared to single treatment for the snails respectively. Toxicity of latex powder+rutin against snail $L$. acuminata is $\mathrm{LC}_{50}=1.02 \mathrm{mg} / \mathrm{L}(24 \mathrm{~h})$ and $I$. exustus is $\mathrm{LC}_{50}=4.45 \mathrm{mg} / \mathrm{L}(24 \mathrm{~h})$ was highest and latex powder+ellagic acid against snail L. acuminata $\left(\mathrm{LC}_{50}\right.$ $=3.14 \mathrm{mg} / \mathrm{L})$ and $I$. exustus is $\left(\mathrm{LC}_{50}=6.40 \mathrm{mg} / \mathrm{L}\right)$. Same trend was also observed in binary combinations with latex powder+taraxerol against freshwater snails L. acuminata and I. exustus. The order of toxicity of binary combinations against both the freshwater snails was decreased 
Table 2

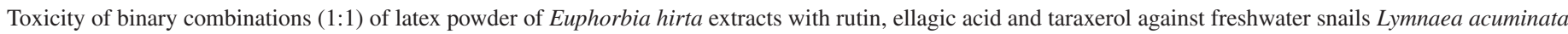
at different time exposure periods

\begin{tabular}{|c|c|c|c|}
\hline \multirow[t]{2}{*}{$\mathrm{Hr}$} & \multicolumn{3}{|c|}{ Lymnaea acuminata } \\
\hline & Compounds & $\mathrm{LC}_{50}(95 \%$ confidence limits $)$ & Slope value \\
\hline \multirow[t]{3}{*}{$24 \mathrm{~h}$} & Latex powder+Rutin & $1.02(0.940-1.118)$ & $2.419 \pm 0.117$ \\
\hline & Latex powder+Ellagic acid & $3.14(2.931-3.469)$ & $4.444 \pm 0.280$ \\
\hline & Latex powder+Taraxerol & $9.46(8.957-10.11)$ & $3.990 \pm 0.215$ \\
\hline \multirow[t]{3}{*}{$48 \mathrm{~h}$} & Latex powder+Rutin & $0.76(0.712-0.824)$ & $2.473 \pm 0.113$ \\
\hline & Latex powder+Ellagic acid & $2.71(2.538-2.979)$ & $4.215 \pm 0.256$ \\
\hline & Latex powder+Taraxerol & $8.38(8.063-8.750)$ & $4.189 \pm 0.208$ \\
\hline \multirow[t]{3}{*}{$72 \mathrm{~h}$} & Latex powder+Rutin & $0.61(0.559-0.662)$ & $2.680 \pm 0.114$ \\
\hline & Latex powder+Ellagic acid & $2.47(2.339-2.654)$ & $3.711 \pm 0.244$ \\
\hline & Latex powder+Taraxerol & $7.06(6.828-7.316)$ & $4.390 \pm 0.199$ \\
\hline \multirow[t]{3}{*}{$96 h$} & Latex powder+Rutin & $0.51(0.446-0.585)$ & $2.546 \pm 0.114$ \\
\hline & Latex powder+Ellagic acid & $1.99(1.895-2.096)$ & $4.387 \pm 0.245$ \\
\hline & Latex powder+Taraxerol & $6.04(5.820-6.274)$ & $4.025 \pm 0.191$ \\
\hline
\end{tabular}

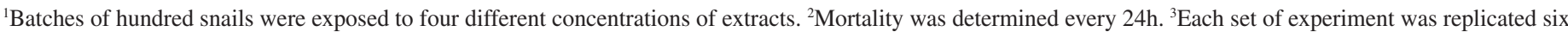

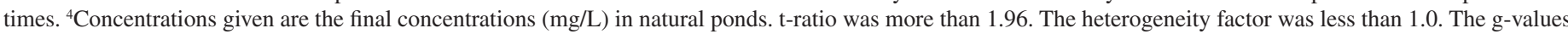

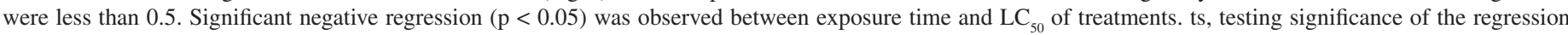

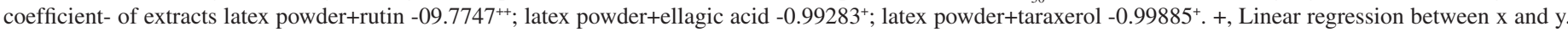
++ , Non-linear regression between $\log \mathrm{x}$ and $\log \mathrm{y}$.

Table 3

Toxicity of tertiary combinations (1:1:1) of latex powder of Euphorbia hirta with rutin, taraxerol, ellagic acid and betulin against Lymnaea acuminata at different time exposure periods

\begin{tabular}{|c|c|c|c|}
\hline \multirow[t]{2}{*}{$\mathrm{hr}$} & \multirow[t]{2}{*}{ Compounds } & \multicolumn{2}{|l|}{ Lymnaea acuminata } \\
\hline & & $\mathrm{LC}_{50}(95 \%$ confidence limits $)$ & Slope value \\
\hline \multirow[t]{3}{*}{$24 \mathrm{~h}$} & Latex powder+Rutin + Betulin & $0.92(0.832-1.047)$ & $2.336 \pm 0.114$ \\
\hline & Latex powder+Ellagic acid+Betulin & $1.57(1.465-1.743)$ & $3.846 \pm 0.230$ \\
\hline & Latex powder+Taraxerol +Betulin & $3.30(3.130-3.536)$ & $3.992 \pm 0.212$ \\
\hline \multirow[t]{3}{*}{$48 \mathrm{~h}$} & Latex powder + Rutin + Betulin & $0.67(0.614-0.738)$ & $2.358 \pm 0.109$ \\
\hline & Latex powder + Ellagic acid + Betulin & $1.33(1.246-1.440)$ & $4.371 \pm 0.224$ \\
\hline & Latex powder + Taraxerol + Betulin & $2.90(2.768-3.076)$ & $4.174 \pm 0.204$ \\
\hline \multirow[t]{3}{*}{$72 \mathrm{~h}$} & Latex powder + Rutin + Betulin & $0.57(0.499-0.644)$ & $2.978 \pm 0.117$ \\
\hline & Latex powder + Ellagic acid + Betulin & $1.10(1.014-1.211)$ & $3.438 \pm 0.204$ \\
\hline & Latex powder + Taraxerol + Betulin & $2.44(2.344-2.556)$ & $4.157 \pm 0.195$ \\
\hline \multirow[t]{3}{*}{$96 \mathrm{~h}$} & Latex powder + Rutin + Betulin & $0.47(0.396-0.550)$ & $2.633 \pm 0.114$ \\
\hline & Latex powder + Ellagic acid + Betulin & $0.86(0.775-0.943)$ & $3.304 \pm 0.204$ \\
\hline & Latex powder + Taraxerol + Betulin & $2.30(1.887-2.170)$ & $4.926 \pm 0.205$ \\
\hline
\end{tabular}

${ }^{1}$ Batches of hundred snails were exposed to four different concentrations of extracts. ${ }^{2}$ Mortality was determined every $24 \mathrm{~h} .{ }^{3}$ Each set of experiment was replicated six times. ${ }^{4}$ Concentrations given are the final concentrations $(\mathrm{mg} / \mathrm{L})$ in earthen cemented ponds. t-ratio was more than 1.96 . The heterogeneity factor was less than 1.0 . The g-values were less than 0.5. Significant negative regression $(\mathrm{p}<0.05)$ was observed between exposure time and $\mathrm{LC}_{50}$ of treatments. ts, testing significance of the regression coefficient- of extracts latex powder+rutin+betulin $-0.96936^{++}$; latex powder+ellagic acid+betulin $-0.99996^{++}$; latex powder+taraxerol+betulin $-0.98044^{++}$. + , Linear regression between $\mathrm{x}$ and $\mathrm{y} .++$, Non-linear regression between $\log \mathrm{x}$ and $\log \mathrm{y}$. 


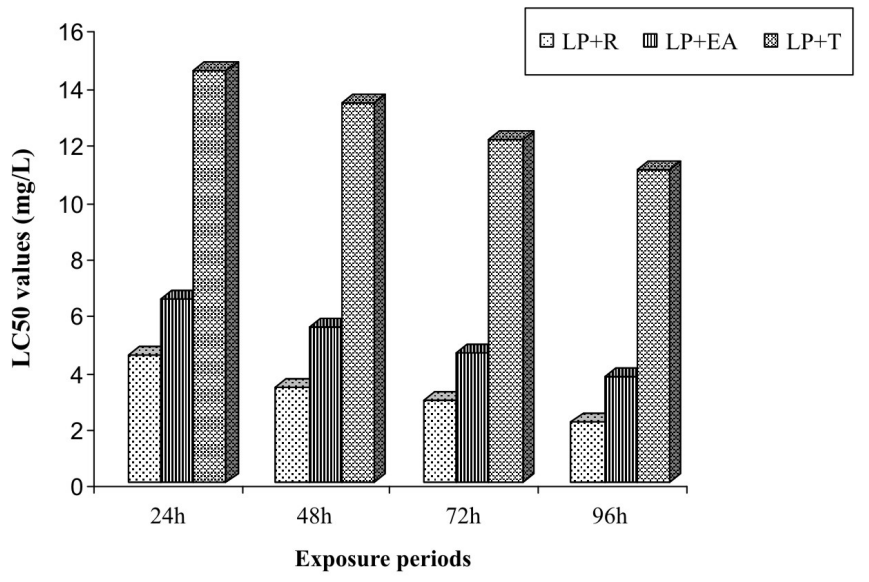

Fig 1 - Histogram showing the toxicity $\left(\mathrm{LC}_{50}\right)$ of $(\mathrm{LP}+\mathrm{R}=$ Latex powder + rutin, $\mathrm{LP}+\mathrm{EA}$ $=$ Latex powder + ellagic acid, $\mathrm{LP}+\mathrm{T}=$ Latex powder + taraxerol) against freshwater snail Indoplanorbis exustus at different exposure periods

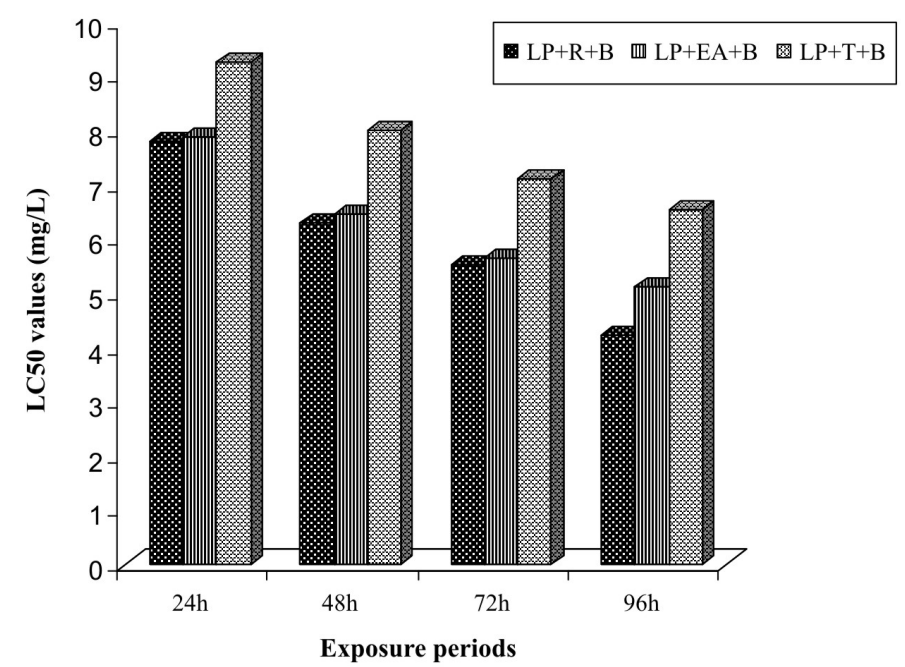

Fig 2 - Histogram showing the toxicity $\left(\mathrm{LC}_{50}\right)$ of $(\mathrm{LP}+\mathrm{R}+\mathrm{B}=$ Latex powder + rutin + betulin, $\mathrm{LP}+\mathrm{EA}+\mathrm{B}=$ Latex powder + ellagic acid + betulin, $\mathrm{LP}+\mathrm{T}+\mathrm{B}=$ Latex powder + taraxerol + betulin) against freshwater snail Indoplanorbis exustus at different exposure periods.

up to latex powder+rutin> latex powder+ellagic acid $>$ latex powder + taraxerol (Tables 3 and 4).

The toxicity of the tertiary combinations (1:1:1) of latex powder of E. hirta mixed with taraxerol, rutin, ellagic acid and betulin against freshwater snails L. acuminata. Toxicity of the tertiary combinations of latex powder+rutin+betulin against freshwater snails $L$. acuminata $\left(\mathrm{LC}_{50}=\right.$ $0.92 \mathrm{mg} / \mathrm{L}$ ) was highest in Table 3 . The order of toxicity of various tertiary combinations against snail L. acuminata was latex powder+rutin+betulin $>$ latexpowder + ellagicacid + betulin $>$ latex powder + taraxerol + betulin . Same trend was also observed in the freshwater snail Indoplanorbis exustus in tertiary combinations. In control group of the animals no toxicity shows with all the treatments.

At higher doses latex powder of E. hirta and compound rutin, betulin, taraxerol and ellagic acid were effective against the snails, and would also cause death amongst the fish. Consequently mixed populations of 50 snails (Lymnaea acuminata) and 50 fishes (Channa punctatus) were treated with the $24 \mathrm{~h} \mathrm{LC}_{90}$ of snails, there was no mortality amongst the fish in earthen cemented pond (Table 4).

Statistical analysis of the data on the toxicity brings several important points. The $\chi^{2}$ - test for goodness of fit (heterogeneity) demonstrated that the mortality counts were not found to be significantly heterogeneous and other variables, for example, resistance, did not significantly affect the $\mathrm{LC}_{50}$ values, as these were within the $95 \%$ confidence limits. The dose mortality graphs exhibited steep slope values. The steepness of the slope line indicated a large increase in the mortality of snails with a relatively small increase in the concentration of the toxicant.

\section{DISCUSSION}

It is evident from the results that latex powder of Euphorbia hirta Linn and compound rutin, betulin, taraxerol and ellagic acid is toxic against both the freshwater snails Lymnaea (Radix) acuminata (Lamarck 1822) and Indoplanorbis exustus (Deshayes 1834) (Tables 2-3, Fig. $1,2)$. Toxicity data from the present study shows that latex powder of Euphorbia hirta and rutin, betulin, taraxerol and ellagic acid have potent molluscicidal activity. The extracts of above caused significant behavioral changes in Lymnaea acuminata and Indoplanorbis exustus with the most obvious sign of distress being muscular and spiral twisting of the body, followed by crawling on one another. The nature and rapid onset of these behavioral responses shows the extracts probably contains neurotoxins, which amongst other things, might be active at the neuromuscular system of the exposed animals. Similar behavior responses have been observed by SINGH \& AGARWAL ${ }^{16}$ in their laboratory study on acute toxicity of lattices of Euphorbia royleana, Euphorbia antisyphiliatica and Euphorbia tiruculi on snail Lymnaea acuminata.

No behavioral symptoms nor death occurred in control groups not placed in treated water, indicating that no factor other than plant moieties were responsible for the altered behaviour and mortality. The concentration dependant response of the animal could be due to several factors, such as rate of penetration, slope, variability and maximal effect ${ }^{6}$.

In laboratory conditions the $\mathrm{LC}_{50}$ values of the tested latex powder of E. hirta against Lymnaea acuminata was $1.29 \mathrm{mg} / \mathrm{L}(24 \mathrm{~h})$ to 0.59 $\mathrm{mg} / \mathrm{L}$ (96h) respectively and $0.97 \mathrm{mg} / \mathrm{L}$ (24h) to $0.34 \mathrm{mg} / \mathrm{L}$ (96h) against Indoplanorbis exustus ${ }^{20}$. In pond the toxicity of $E$. hirta latex powder was against $L$. acuminata is $7.31 \mathrm{mg} / \mathrm{L}(24 \mathrm{~h})$ to $3.93 \mathrm{mg} / \mathrm{L}$ (96h) respectively, and $6.08 \mathrm{mg} / \mathrm{L}$ (24h) to $2.30 \mathrm{mg} / \mathrm{L}$ (96h) was the freshwater snail I. exustus.

The reason for reduced toxicity could be due to soil particle adsorption $^{5}$ or acceleration of the toxicant degradation process by temperature. A similar trend was reported by PERSCHBACHER \& SARKAR ${ }^{13}$ in which the toxicity persistence of Masea ramentacea and tea seed cake was short and fish could be stocked into ponds four days applying the plant pesticides.

Increased mortality with increased exposure periods could be effected by several factors, which may be acting separately or conjointly. For example, uptake of active moiety is time dependent, which leads progressive increase the entrance of the drug and its effects in the snail body ${ }^{16}$. Stability (life span) of active moiety of pesticides in environment 
Table 4

Percent mortality (mean $\pm \mathrm{SE}$ ) of Lymnaea acuminata and Channa punctatus caused by (i.e. $24 \mathrm{~h} \mathrm{LC}_{90}$ of snail) latex powder, binary and tertiary combinations of compounds after $24 \mathrm{~h}$ exposure period

\begin{tabular}{|c|c|c|c|}
\hline Compound & Experimental animals & Concentrations $\mathrm{LC}_{90}(\mathrm{mg} / \mathrm{L})$ & $\%$ mortality \\
\hline \multirow[t]{2}{*}{ Latex powder } & L. acuminata & 9.05 & $91.6 \pm 2.31$ \\
\hline & C. punctatus & - & 0 \\
\hline \multirow[t]{2}{*}{ Latex powder+rutin } & L. acuminata & 3.45 & $93.3 \pm 1.15$ \\
\hline & C. punctatus & - & 0 \\
\hline \multirow[t]{2}{*}{ Latex powder+ellagic acid } & L. acuminata & 6.10 & 100 \\
\hline & C. punctatus & - & 0 \\
\hline \multirow[t]{2}{*}{ Latex powder+taraxerol } & L. acuminata & 10.82 & $96.2 \pm 1.00$ \\
\hline & C. punctatus & & \\
\hline \multirow[t]{2}{*}{ Latex powder+rutin+betulin } & L. acuminata & 3.28 & $93.6 \pm 0.31$ \\
\hline & C. punctatus & - & \\
\hline \multirow[t]{2}{*}{ Latex powder+elllagic acid+betulin } & L. acuminata & 2.96 & $95.6 \pm 3.31$ \\
\hline & C. punctatus & - & \\
\hline \multirow[t]{2}{*}{ Latex powder+taraxerol+betulin } & L. acuminata & 3.21 & $97.6 \pm 1.31$ \\
\hline & C. punctatus & - & \\
\hline
\end{tabular}

Each pond contained 50 fish (Channa punctatus) and 50 snails (Lymnaea acuminata) in 30L dechlorinated tap water. There was no mortality in case of control group. - , no mortality.

and the rate of their detoxification in animal body also alter the mortality and exposure periods, relationship ${ }^{11}$.

Statistical analysis of the data on toxicity brings out several important points. The $\chi^{2}$ test for goodness of fit (heterogeneity) demonstrated that the mortality counts were not found to be significantly heterogeneous and other variables, e.g., resistance etc. do not significantly affect the $\mathrm{LC}_{50}$ values, as these were found to lie within the $95 \%$ confidence limits. The slope is, thus an index of the susceptibility of the target animal to the plant molluscicides. A steep slope is also indicative of rapid absorption and onset of effects. Even though the slope alone is not a very reliable indicator of toxicological mechanism, yet it is a useful parameter, for such a study. Since the $\mathrm{LC}_{50}$ of the extracts lay within the $95 \%$ confidence limits, it is obvious that in replicate test of random samples, the concentration response lines would fall in the same range ${ }^{14}$.

In conclusion it may be stated that singly, binary $(1: 1)$ and tertiary $(1: 1: 1)$ combinations of latex powder with other plant derived molluscicides can be used in the earthen cemented ponds to control the population of vector snails and can potentiate the efficacy and reduce the doses of plant derived molluscicides.

\section{RESUMO}

\section{Eficácia do látex da Euphorbia hirta como moluscicida vegetal contra caramujos de água doce}

Os efeitos tóxicos das combinações binárias e terciárias do pó de látex da Euphorbia hirta Linn assim como outros compostos vegetais moluscicidas foram avaliados em sua ação sobre caramujos de água doce
Lymnaea (Radix) acuminata e Indoplanorbis exustus em represas. Estas combinações mostraram significante efeito dose e tempo dependente contra ambos os caramujos. Estes compostos em doses altas foram também letais para peixes de água doce Channa punctatus (Bloch) (Channidae \{Ophicephalidae\}), que compartilham o ambiente com estes caramujos mas a dose $\mathrm{LC}_{90}(24 \mathrm{~h})$ para caramujos aparentemente não tem propriedade de matar as populações de peixes quando uma população mista de peixes e caramujos são tratadas.

\section{ACKNOWLEDGEMENTS}

One of the Authors (Ram P. Yadav) is thankful to Council of Scientific and Industrial Research, Govt. of India, New Delhi for award of the Pool Scientist Fellowship (CSIR sanction No. 13(8190-A)/Pool/2007 dated 4-12-2007) for financial Assistance.

\section{REFERENCES}

1. American Public Health Association (APHA). Standard methods for the examination of water and wastewater. Washington: APHA;1992. p. 1268.

2. Bhatnagar VP, Anil K, Srivastava JN. Wild medicinal herbs of Agra. J Med Aromat Plant Sci. 2000;22-23:464-7.

3. Brackenbury TD, Appleton C. Plant molluscicides in South Africa: a registration dilemma. Parasitol Today. 1998;14:83-4.

4. Chopra RN, Chopra IC, Verma VS. Supplement to glossary of Indian medicinal plants. New Delhi: Council of Scientific \& Industrial Research; 1969.

5. Dawson VK, Gingerich WH, Davis RA, Gilderhus PA. Rotenone persistence in freshwater ponds: effects of temperature and sediment adsorption. North Am J Fish Manag. 1991;11:226-31. 
6. Goodman LS, Gilman AG, Rall TW, Murad F, editors. The pharmacological basis of therapeutics. $7^{\text {th }}$ ed. New York: Macmillan; 1985.

7. Jain SK. Medicinal plants. $6^{\text {th }}$ ed. New Delhi: National Book Trust; 1969.

8. Kapoor SL, Mitra R. Herbal drugs in Indian pharmaceutical industry. Lucknow, India: National Botanical Research Institute; 1979. 85p.

9. Marston A, Hostettmann K. Plant molluscicides. Phytochem. 1985;24:639-52.

10. McCullough FS. Snail control in relation to a strategy for reduction of morbidity due to schistosomiasis. Trop Med Parasitol. 1986;37:181-4.

11. Mitra PK, Sud SC, Bahga HC. Acute oral toxicity of metasystoxin in buffalo calves. Indian J Exp Biol. 1978;16:813-5.

12. Nadkarni KM. The Indian Materia medica. $3^{\text {rd }}$ ed. Bombay: Popular Prakashan; 1976.

13. Perschbacher PW, Sarkar J. Toxicity of selected pesticides to the snakehead, Channa punctata. Asian Fish Sci. 1992;2:249-54.

14. Rand GM, Petrocelli SR, editors. Fundamentals of aquatic toxicology. New York: Hemisphere Publishing; 1988. p. 415.

15. Robertson JL, Russell RM, Preisler HK, Savin NE. Bioassay with Arthropods: POLO computer programme for analysis of bioassay data. $2^{\text {nd }}$ ed. Boca Raton: CRC Press; 2007. p. 1-224.

16. Singh A, Agarwal RA. Possibility of using latex of euphorbiales for snail control. The Sci Total Environ. 1988;77:231-6.

17. Singh A, Singh DK, Misra TN, Agarwal RA. Molluscicides of plant origin. Biol Agric Hortic. 1996;13:205-52.

18. Singh K, Singh A, Singh DK. Molluscicidal activity of different combinations of the plant products used in the molluscicides Pestoban. Biol Agric Hortic. 1995;12:253-61.

19. Singh O, Agarwal RA. Toxicity of certain pesticides to two economic species of snails in northern India. J Econ Entomol. 1981;74:568-71.
20. Singh SK, Yadav RP, Singh A. Molluscicidal activity of Euphorbia hirta plant against freshwater vector snails. In: Proceedings of National Symposium on Biochemical Sciences: Health and Environmental Aspects. Agra; 2003. p. 290-4.

21. Singh SK, Yadav RP, Singh A . Molluscicides from some common medicinal plants of Eastern Uttar Pradesh, India. J Appl Toxicol. 2010;30:1-7.

22. Sokal RR, Rohlf FJ. Introduction of biostatistics. San Francisco: WH Freeman; 1973 p. 368.

23. Yadav RP, Tiwari S, Singh A. Toxic effect of Taraxerol extracted Codiaeum variegatum stem bark on target vector snail Lymnaea acuminata and non-target fish. Iberus. 2005;23(1):1-13.

24. Yadav RP, Singh A. Toxic effects of Jatropha gossypifolia and its binary and tertiary combinations with other plant molluscicides in natural ponds. Iberus. 2006.24(2):4754.

25. Yadav RP, Singh A. Toxic effects of Euphorbials on freshwater snail Lymnaea acuminata in ponds. J Herb Spic Med Plants. 2007;13(2):87-94.

26. Yadav RP, Singh A. Combinations of binary and tertiary toxic effects of extracts of Euphorbia pulcherima latex powder with other plant derived molluscicides against freshwater vector snails. Internet J Toxicol. 2009;7(1).

27. Yadav RP, Singh A. Euphorbious plants used as molluscicides and piscicides: a review. In: Gupta VK, editor. Comprehensive Bioactive Natural Products. Houston: Studium Press LLC; 2010. v. 2, p. 449-60.

28. Yadav RP, Singh A. Toxic effects of Crotocaudin extracted from medicinal plant Croton tiglium stem bark on the vector snail and freshwater fish. Z. Naturforsch. 2010;65c:327-36.

Received: 25 February 2010

Accepted: 18 October 2010. 